\title{
Sociodemographic And Social Activities Factors Associated With Premarital Sex Behaviour Among Late Adolescents In Semarang
}

\author{
Putri Febrianti $^{1^{*}}$, Ari Udijono1, Lintang Dian Saraswati ${ }^{1}$ \\ ${ }^{1}$ Epidemilogy and Tropical Disease, Faculty of Public Health, Diponegoro University \\ *Correspondence author: putrifebrianti99@gmail.com
}

\begin{abstract}
Introduction: Premarital sexual behavior is one of the complex problems faced by adolescents. This behavior is increasingly prevalent throughout the world, especially in Indonesia. This study aims to determine the sociodemographic factors (gender, and monthly allowance) and social activities related to premarital sexual behavior in late adolescence in Semarang City.

Methods : This research is a quantitative study with a cross sectional approach. The number of samples was 400 respondents aged 18-22 years using consecutive sampling technique. This study used univariate and bivariate analysis using the chi-square test.

Results: The results showed that gender $(p=0,000)$, monthly allowance $(p=0,000)$ and social activity $(p=0,000)$ had a relationship with premarital sexual behavior in late adolescence.

Conclusion: It is necessary to establish youth programs at SMA / SMK / equivalent and university levels to develop self-confidence and life skills with an increasing the ability of adolescents to avoid and / or reduce risky sexual behavior.
\end{abstract}

Keywords: premarital sex, sexual behavior, adolescent, Semarang 


\section{Introduction}

Premarital sexual behavior among adolescents is reported to have increased throughout the world, one of which is in Indonesia. Premarital sexual behavior among adolescents is a serious public health problem. This can lead to unwanted pregnancies, unsafe abortions, sexually transmitted infections including HIV / AIDS which in turn can have a negative impact on academic achievement and mental health problems for adolescents. Based on BKKBN data, it is known that $46 \%$ of adolescents aged 15-19 years have had premarital sexual intercourse. These results are supported by Komnas 2012 research on premarital sexual behavior among junior and senior high school adolescents in 17 major cities in Indonesia with a total number of respondents of 4,726 indicating that $97 \%$ had watched pornography, $93.7 \%$ had had sexual intercourse, and $21.2 \%$ have had an abortion before. ${ }^{1,2}$

Sexual intercourse among adolescents can increase the risk of getting sexually transmitted infections, including HIV / AIDS. HIV / AIDS is a health problem around the world, including Indonesia. Semarang City is one of the areas with a high spread of the HIV / AIDS virus. It is known that there are 2,182 people infected with HIV / AIDS in the city of Semarang. According to Zainal Abidin, Secretary of Central Java KPA, stated that there were 47,514 Central Java residents who were infected with HIV / AIDS. However, until June 2018, the Central Java KPA had only been able to find 23,603 people with HIV / AIDS, with 1,672 of whom had died. ${ }^{3}$

Researches on adolescents in Indonesia generally conclude that Indonesian adolescents, especially in urban areas, are more tolerant of premarital sexual lifestyles. One of the causes of this is the rapid flow of information that can lead to sexual stimulation in adolescents in urban areas, thus encouraging adolescents to be more permissive and have premarital sexual intercourse. ${ }^{4}$

Other factors that have a relationship with premarital sexual behavior in adolescents are puberty age, gender, education level, parental supervision, level of knowledge about sexual and reproductive health, attitudes, and place of residence. Wepukhulu et al., (2012) also concluded that the high rate of premarital sexual behavior among adolescents is influenced by socio-economic factors, one of which is an allowance per month. Mahampang's research shows that there is an influence of gender, exposure to sexual sources of information and attitudes towards premarital sexual behavior. ${ }^{4}$ Another factor that influences premarital sexual behavior is the area of residence or domicile. Based on research conducted by Kamarudin in Malaysia in 2018, it is known that the proportion of adolescents who have had sexual intercourse is higher in urban areas, namely $9.3 \%$ while in rural areas it is only $5.3 \% .^{5}$

The increasing percentage of adolescents who have had premarital sex will also have an impact on the increase in cases of unwanted pregnancy, sexually transmitted infections including HIV / AIDS, early age marriage, unsafe abortion, mental health problems and other social impacts in society.

The increasing percentage of adolescents who have premarital sexual intercourse and the many factors that influence this behavior encourage researchers to conduct an analysis of sociodemographic factors and social activities related to premarital sexual behavior in adolescents. This research was conducted in Semarang City with the age range of 18-22 years old or late adolescents.

\section{Methods}

This research is a quantitative study with a cross-sectional study approach. Data collection was carried out in October 2020. Data was collected using a google form that was distributed through social media according to the situation and conditions during the Covid-19 pandemic. The target population in this study were all residents of Semarang City with a total of 1.680 .417 people. The number of samples in this study were 400 respondents. Data analysis was performed univariate and bivariate with chi-square test using a 95\% confidence interval and a significance limit ( $\alpha$ ) of 0.05 , with the result that if the $p$ value $<0.05$, the 
results were considered statistically significant.

\section{Results}

Table 1 shows an overview of the sociodemographic characteristics of the respondents. Most of the respondents were 21 years old $(24,5 \%)$, female $(68,3 \%)$, have recent education level senior high school $(76,3 \%)$ and had an allowance per month below the average $(61,5 \%)$.

Table 1. Frequency and Central Tendency of Sociodemographic Characteristics of Respondent

\begin{tabular}{|c|c|c|}
\hline Sociodemographic Characteristic & $\begin{array}{c}\text { Frequency } \\
\text { (n) }\end{array}$ & $\%$ \\
\hline \multicolumn{3}{|l|}{ Aqe } \\
\hline 1. 18 years old & 66 & 16.5 \\
\hline 2. 19 years old & 85 & 21.3 \\
\hline 3. 20 years old & 66 & 16.5 \\
\hline 4. 21 years old & 98 & 24.5 \\
\hline 5. 22 years old & 85 & 21.3 \\
\hline \multicolumn{3}{|l|}{ Sex } \\
\hline 1. Female & 273 & 68.3 \\
\hline 2. Male & 127 & 31.8 \\
\hline \multicolumn{3}{|l|}{ Education level } \\
\hline \multicolumn{3}{|l|}{ 1. Junior high school } \\
\hline \multicolumn{3}{|l|}{$\begin{array}{l}\text { 2. Senior high school } \\
\text { 3. Diploma }\end{array}$} \\
\hline 4. Bachelor & 305 & 76.3 \\
\hline \multicolumn{3}{|l|}{ Allowance per month } \\
\hline 1. Above average & 246 & 61.5 \\
\hline 2. Under average & 154 & 38.5 \\
\hline
\end{tabular}

Based on table 2, it is known that most respondents have high social activity $(94,3 \%)$, while only a small proportion of respondents have low social activity $(5,8 \%)$.

Table 2. Frequency Distribution of Respondents Social Activities

Social Activites $\quad$ Frequency $\%$

(n)

\begin{tabular}{ccc}
\hline High & 377 & 94.3 \\
\hline Low & 23 & 5.8 \\
\hline Total & 400 & 100.0 \\
\hline
\end{tabular}

Based on table 3 , it is known that more than half of the respondents had premarital sexual behavior $(54,3 \%)$, while only a few respondents did not have premarital sexual behavior (45,8\%).

Table 3. Frequency Distribution of Respondents Premarital Sexual Behavior Premarital Sexual Behavior $\quad$ Frequency $\%$

(n)

\begin{tabular}{ccc}
\hline Yes & 217 & 54.3 \\
\hline No & 183 & 45.8 \\
\hline
\end{tabular}




\begin{tabular}{|c|c|}
\hline Total & 100.0 \\
\hline $\begin{array}{l}\text { Based on table } 4 \text {, it is known that } \\
73,75 \% \text { of respondents who had sexual } \\
\text { behavior had held hands, } 53,25 \% \text { had } \\
\text { kissed lips, touched / touched sensitive } \\
\text { parts of the body, } 64.5 \%, 27,25 \% \text { had ever } \\
\text { done petting, } 28 \% \text { had oral sex, } 4 \% \text { had }\end{array}$ & $\begin{array}{l}\text { anal sex, } 26,25 \% \text { had genital sex and } 8 \% \\
\text { had genital sex with someone other than } \\
\text { their partner. Sexual behavior which is } \\
\text { categorized as not at risk is holding hands, } \\
\text { while from lip kissing to abortion is risky } \\
\text { sexual behavior. }\end{array}$ \\
\hline
\end{tabular}

Table 4. Frequency Distribution of Sexual Behaviors by Respondents

\begin{tabular}{lll}
\hline Premarital Sexual Behavior & $\mathbf{f}$ & $\%$ \\
\hline Holding hands & 295 & 73.75 \\
\hline Kissing & 213 & 53.25 \\
\hline Touching sensitive parts of the body & 258 & 64.5 \\
\hline Petting & 109 & 27.25 \\
\hline Oral sex & 112 & 28 \\
\hline Anal sex & 16 & 4 \\
\hline Genital sex & 105 & 26.25 \\
\hline Genital sex with other current partner & 32 & 8 \\
\hline Abortion & 2 & 0.5 \\
\hline Total & 400 & 100.0 \\
\hline
\end{tabular}

\section{Discussions}

\section{The relationship between gender and} premarital sexual behavior

Respondents who had premarital sexual behavior were mostly found in male respondents, namely $74 \%$ and respondents who did not have premarital sexual behavior were found mostly in female respondents, namely $54,9 \%$.

The results of the chi square test showed $\mathrm{p}$-value $=0.000<0.05$ where $\mathrm{Ha}$ was accepted and Ho was rejected, so it could be concluded that there was a significant relationship between gender and premarital sexual behavior. In previous research, it is known that male adolescents tend to have a greater risk of sexual behavior than female adolescents. Teenage boys have sexual fantasies more easily and are more daring to engage in sexual behavior. Meanwhile, adolescent girls can still hold back because of the shame and moral burdens they feel. 6,7 
Table 5. Results of the Bivariate Test for Premarital Sexual Behavior in Adolescents

\begin{tabular}{|c|c|c|c|c|c|c|c|}
\hline \multirow{3}{*}{ Variable } & \multicolumn{4}{|c|}{ Premarital Sexual Behavior } & & \multirow{2}{*}{ Amount } & \multirow{2}{*}{$\begin{array}{l}\quad p \\
\text { valu } \\
\mathrm{e}\end{array}$} \\
\hline & \multicolumn{2}{|c|}{ Yes } & \multicolumn{2}{|c|}{ No } & & & \\
\hline & f & $\%$ & $f$ & $\%$ & f & $\%$ & \\
\hline Sex & & & & & & & \\
\hline 1. Female & 237 & 55.8 & 188 & 44.2 & 425 & 100.0 & 0.000 \\
\hline 2. Male & 122 & 78.7 & 33 & 21.3 & 155 & 100.0 & \\
\hline $\begin{array}{l}\text { Allowance per } \\
\text { month }\end{array}$ & & & & & & & \\
\hline 1. Above & 149 & 77.6 & 43 & 22.4 & 192 & 100.0 & \\
\hline average & & & & & & & 0.000 \\
\hline $\begin{array}{l}\text { 2. Under } \\
\text { average }\end{array}$ & 210 & 54.1 & 178 & 45.9 & 388 & 100.0 & \\
\hline Social Activities & & & & & & & \\
\hline 1. High & 345 & 64.1 & 193 & 35.9 & 538 & 100.0 & 0.000 \\
\hline 2. Low & 14 & 33.3 & 28 & 66.7 & 42 & 100.0 & \\
\hline
\end{tabular}

The relationship between allowance per month and premarital sexual behavior

The allowance per month is the amount of money received by the respondent to meet their daily needs within a month. In this study, the allowance earned is related to a person's economic status. The higher the monthly allowance received by a person indicates that the person has a good economic status so that the higher the chance for that person to access information media. ${ }^{9}$

From table 5 it can be seen that the proportion of respondents with premarital sexual behavior mostly had an allowance per month above the average of $61,4 \%$ and the majority of respondents who did not have premarital sexual behavior had an allowance per month below the average of $42,9 \%$.

The results of the chi square test showed $\mathrm{p}$-value $=0.000<0.05$, where $\mathrm{Ha}$ was accepted and Ho was rejected. This means that there is a significant relationship between allowance per month and premarital sexual behavior. This is supported by research conducted by Wepukhulu et al., (2012) which was conducted in Kenya. It is known that economic status is a variable related to adolescent sexual behavior. Meanwhile, it is different from the research conducted by Kamarudin (2018) where the economic status variable has no relationship with adolescent sexual behavior. This research is supported by research conducted by Isiugo-Abanihe \& Oyediran (2004) who found that allowance per month was not related to adolescent sexual behavior. ${ }^{5}$

The relationship between social activities and premarital sexual behavior

Social activities are activities that are carried out simultaneously with the community in the surrounding environment. A teenager can interact socially with the surrounding community and carry out social activities by participating in activities in the area that will influence adolescent sexual behavior. In this study, the social activities referred to consist of going to night clubs, cafes, cinemas, smoking and drinking alcohol (Koentjaraningrat, 1989).., 10 
Based on table 5 , it is known that the proportion of respondents with premarital sexual behavior in the majority has high social activity, which is $56 \%$, this is directly proportional to the proportion of respondents who do not have premarital sexual behavior where most of them have low social activity, namely $73,9 \%$.

The results of the chi square test showed $p$-value $=0.005<0.05$, where $\mathrm{Ha}$ was accepted and Ho was rejected. This means that there is a significant relationship between social activities and premarital sexual behavior. This is in line with research conducted by Suryoputro (2006) which states that social activities consisting of going to discos, night clubs, smoking and drinking alcohol are factors that are associated with the occurrence of premarital sexual relations in the student sample $(p<0.05)$. . This means that student respondents who have high social activity are almost six times more likely to have premarital sexual relations with an OR of 5.74 than those with low social activity. ${ }^{11,12}$

\section{Conclusions}

The dominant age of the respondent is 21 years $(24,5 \%)$. Most of the respondents are female (68.3\%). More than half of the respondents had recent education level senior high school (76.3\%). The majority of respondents have an allowance per month above the average $(61,5 \%)$. Factors related to premarital sexual behavior in late adolescents in Semarang City are gender $(p=0,000)$, monthly allowance $(p=0,000)$, and social activity $(p=0,000)$. Based on the research results, it is known that social activities have a relationship with adolescent premarital sexual behavior. Therefore, it is necessary to establish youth programs at SMA / SMK / equivalent and university levels to develop self-confidence and life skills with an increasing the ability of adolescents to avoid and / or reduce risky sexual behavior.

\section{References}

1. Appulembang YA, Fajar NA, Tarigan AHZ. Peran Keluarga dalam Upaya Pencegahan Perilaku Seks Pranikah Remaja di Palembang. Analitika.
2019;11(2):151.

2. Adeoye. Prevalence of premarital sex and factors influencing it among students in a private tertiary institution in Nigeria. Int $\mathrm{J}$ Psychol Couns [Internet]. 2012;4(1):6-9. Available from: https://academicjournals.org/journal /IJPC/article-full-textpdf/80BBB7738361

3. Kevin M, Ariayudha A, Husodo BT, Prabamurti PN. Perilaku Seksual Pranikah Mahasiswi Studi Kasus Perguruan Tinggi Favorit Di Kota Semarang. J Kesehat Masy. 2020;8(3):310-4.

4. Mahmudah $M$, Yaunin $Y$, Lestari $Y$. Faktor-Faktor yang Berhubungan dengan Perilaku Seksual Remaja di Kota Padang. J Kesehat Andalas. 2016;5(2):448-55.

5. Kamaruddin K, Razalli R, Ariffin A. Prevalence of Premarital Sexual Intercourse and its Associated Factors: a cross-sectional study among adolescents in Malaysian Secondary School. Int J Acad Res Bus Soc Sci [Internet]. 2018;8(6):1252-64. Available from: http://dx.doi.org/10.6007/IJARBSS/v 8-i6/4513

6. Gayatri S, Shaluhiyah Z, Indraswari R. Faktor Faktor Yang Berhubungan Dengan Frekuensi Akses Pornografi Dan Dampaknya Terhadap Perilaku Seksual Pada Remaja Di Kota Bogor (Studi Di SMA Kota Bogor). J Kesehat Masy. 2020;8(3):410-9.

7. Donevan $M$, Mattebo $M$. The relationship between frequent pornography consumption, behaviours, and sexual preoccupancy among male adolescents in Sweden. Sex Reprod Healthc [Internet]. 2017;12:82-7. Available from: http://dx.doi.org/10.1016/j.srhc.2017 .03.002

8. Mutalip MHA. Factors Associated with Sexual Intercourse, CondomUse, and Perceived Peer Behaviors Among Adolescents in Malaysia: A School-Based Cross-Sectional Study. Malaysian J Soc Sci Humanit [Internet]. 2019;4(2):8-18. Available 
from:

https://www.researchgate.net/public ation/332963539_Factors_Associat ed_with_Sexual_Intercourse_Cond om-

Use_and_Perceived_Peer_Behavio rs_Among_Adolescents_in_Malaysi a_A_School-Based_Cross-

Sectional_Study

9. Folayan $\overline{\mathrm{M} O}$, Adebajo S, Adeyemi A, Ogungbemi KM. Differences in sexual practices, sexual behavior and HIV risk profile between adolescents and young persons in rural and urban Nigeria. PLoS One [Internet]. 2015;10(7):1-14. Available from: https://journals.plos.org/plosone/arti cle? $\mathrm{id}=10.1371 /$ journal . pone. 01291
06

10. Bayer HealthCare Pharmaceuticals. Clueless or clued up: Your right to be informed about contraception. 2011.

11. Suryoputro A, Ford N, Shaluhiyah Z. Faktor-faktor yang mempengaruhi perilaku seksual remaja di Jawa Tengah: implikasinya terhadap kebijakan dan layanan kesehatan seksual dan reproduksi. Makara Kesehat. 2006;10(1):29-40.

12. Cheah YK, Lim HK, Kee CC, Mohd Ghazali S. Demographic and lifestyle factors associated with sexual activity among adolescents in Malaysia. Vulnerable Child Youth Stud. 2016;11(4):324-31. 